\title{
The Legal Provisions Regulating the Finance Lease Contract under the Jordanian Finance Lease Law
}

\author{
Maher J. Aljaber ${ }^{1}$, Asma M. Al-Raqqad ${ }^{1}$, Ali A. Alzubi ${ }^{1}$ \& Asma Ghnimat ${ }^{2}$ \\ ${ }^{1}$ Department of Public and Private Law, Al-Balqa Applied University, Salt, Jordan \\ ${ }^{2}$ Salt, Jordan \\ Correspondence: Maher Aljaber, Department of Public and Private Law, Al-Balqa Applied University, Salt, Jordan. \\ Tel: 962-7-9534-3700. E-mail: maheraljaber@bau.edu.jo
}

Received: June 13, 2020

doi:10.5539/jpl.v14n1p83
Accepted: September 5, 2020

Online Published: December 31, 2020

URL: https://doi.org/10.5539/jpl.v14n1p83

\begin{abstract}
Finance lease is considered a very important method in advanced countries for funding enterprises. It enables facilities to achieve development, growth, and increases productivity. It facilitates the process of getting funds that shall be used for achieving development and using technology. The present study aimed to explore the stand of the Jordanian legislator on the finance lease contract. That is done through shedding a light on thematic and formal requirements of concluding this contract. The researchers aimed to identify the rights and obligations of the lessor and the lessee under the finance lease contract. These things are explored through adopting an analytical approach. Through adopting this approach, the researchers aimed to analyze several legislative texts in the Jordanian Civil Law and the Jordanian Finance Lease Contract Law.
\end{abstract}

Keywords: Jordan, finance lease contract, lessor, lessee, finance lease law

\section{Introduction}

Finance lease is a modern method for funding enterprises and investments. For instance, launching and developing enterprises require having modern equipment and machines. Seeking conventional funding methods may hinder doing that. That's because the latter methods may require meeting strict conditions. Meeting such conditions may lead to the termination of the enterprise. It may lead to freezing part of the capital of the enterprise. Seeking conventional funding methods may require providing securities of major financial worth. Providing such securities may lead to experiencing insolvency. Therefore, finance lease aims at enabling people to launch and develop investments and enterprises. Due to the presence of finance lease contracts, the ones who want to launch or develop an enterprise do not have any more to seek obtaining conventional funding methods.

The finance lease contract emerged during the middle of the $20^{\text {th }}$ century. To be specific, it emerged when "David Bought" established a company named finance lease in the United States. During the 1960s, the finance lease method started to develop more. Such a development increased, especially after having banks involved in finance lease contracts. The involvement of banks in these contracts promoted awareness among the US legislators about the significance of finance lease. Therefore, the US legislators issued an act that grants tax exemptions for the ones practicing finance lease activities.

Under the finance lease contract, the financer (lessor) shall enable the launcher of the enterprise (the lessee) to acquire machine without paying their full prince in advance. Such machines shall be purchased by the financer with acquiring the ownership of the machines. The launcher of the enterprise (the lessee) shall use the machine with providing the financer (lessor) with rentals. He shall keep paying the rental till the contract expires. When the contract expires, the lessee may acquire the ownership of the machines, return the machines to the lessor or renew the finance lease contract.

All countries - including developing countries - seek achieving economic development and growth. Therefore, they carry out enterprises in order to develop their national economy, increase their national income, and improve the living conditions of their citizens. Individuals also seek launching enterprises to incase their income. However, launching enterprises require much money. Therefore, finance lease emerged. It enables people to launch and develop enterprises. It enables people to expand the scope of production. It enables the launcher of an enterprise to do that without enforcing a burden over his shoulders. 
Under the finance lease contract, the launcher of an enterprise shall resort to a financial institution that is specialized in finance lease. He shall present his ideas which require funding. If the institution found that the idea is feasible, the institution shall request the enterprise launcher to choose the required assets. After that, the institution shall buy the assets in its name. Then, it shall lease the assets to the lessee. That shall occur, provided that the lessee pays the rental while using the assets. When the contract between the lessor and the lessee expires, the lessee may acquire the ownership of the machines, return the machines to the lessor or renew the finance lease contract.

\subsection{The Significance of the Study}

The present study is significant because it sheds a light on a very important subject which is finance lease. Finance lease is important because it enables countries to achieve development, advancement, and growth. It is important because it enables countries to expand their scope of production and enjoy economic openness. It is important due to having countries that experience difficulty in funding medium and big enterprises. That is because launching and improving enterprises and raising their productivity require much money. Due to the significance, spread and merits of finance lease contracts, the Jordanian legislator enacted legislative texts that govern such contracts. The present study is significant because the Arab studies -including the Jordanian studies- that address the legislative texts that govern finance lease contracts are scarce. It is significant because there aren't many studies that shed a light on the inadequacy of such legislative texts. It is significant because the extent of concluding such contracts has been increasing.

\subsection{Statement of the Problem and the Used Methodology}

The present study aimed to explore the stand of the Jordanian legislator on the finance lease contract. It aimed to identify the thematic and formal requirements of concluding such a contract under the Jordanian laws, and to identify the rights and obligations of the lessor and the lessee under this contract. To meet the study's goals, the researchers adopted an analytical approach. Through adopting this approach, the researchers aimed to analyze and interpret several legislative texts in the Jordanian finance lease law. Through conducting such an analysis, the researchers aimed to identify the meaning of finance lease, and the thematic and formal requirements of concluding this contract section 2. Through conducting such an analysis, the researchers aimed to identify the rights and obligations of the lessor and the lessee under this contract section 3.

\section{Concluding the Finance Lease Contract}

Money is essential for launching enterprises. That applies regardless of the size of the enterprise. The amount of the capital of enterprises varies from one enterprise to another. It depends on the size, and field of each enterprise. There is no doubt that launching some enterprises require having much money. In addition, the development of some existent enterprises and increasing their productive capacity require having much money. Funding enterprises is a goal sought by all the enterprise launchers to launch or develop an enterprise. Therefore, finance lease emerged to meet such a goal. It is characterized with being free from the demerits of the conventional funding methods (e.g. loans). Through sub-section one, the researchers aimed to identify the meaning and merits of the finance lease contract. Through sub-section two, the researchers aimed to identify the thematic requirements of concluding the finance lease contract. Finally, through sub-section three, the researchers aimed to identify the formal requirements of concluding the finance lease contract.

\subsection{The Definition and Merits of the Finance Lease Contract}

Finance lease contract is considered an important contract that has a great impact on economy. It plays a significant role in boosting the economic development ${ }^{1}$. The Jordanian legislator enacted legislative texts that regulate the latter contract. That was done through enacting the Jordanian finance lease contract No. 45 of 2008. The latter act was published in the official Gazette issue No. 4924 on 17/8/2008.

Finance lease is considered a term that is usually associated with funding through credit. It is has been widely. Through concluding a finance lease contract, the lessor shall lease specific assets to the lessee in order to be utilized. That shall occur, provided that the lessor will keep having the ownership of the leased assets. However, when the finance lease contract expires, the lessee may become the owner of the assets. Thus, finance lease contract include several types of contracts jointly; lease, sale and funding contracts. Thus, three types of contracts are combined jointly in one single contract.

However, when concluding a lease contract, the lessor shall allow the lessee to use the assets for a specific period

\footnotetext{
${ }^{1}$ BAROUD, A. Obstacles to the Application of Financial Leasing as a Tool to Finance Economic Projects: An Applied Study on Non-Banking Financial Institutions Operating in Palestine. Unpublished MA Thesis, Faculty of Law, Islamic University, Gaza. 2011.
} 
of time, provided that the lessee pays rental. As for the sale contract, it is conducted between buyer and the seller. Through concluding a sale contract, the buyer pays a specific amount of money in order to obtain a specific service or acquiring the ownership of an asset. As for the finance contract, it aims at providing an enterprise with funds or certain resources. Each contract of these three contracts may be concluded separately. However, they could be concluded jointly in one single contract (i.e. the finance lease contract) ${ }^{2}$. Therefore, through this section, the researchers aimed to identify the meaning of the finance lease contract. He also aimed to identify the merits of this type of contracts.

\subsubsection{The Meaning of the Finance Lease}

There is a debate among jurists about the expression used in Arabic language for referring to this type of contracts. In Arabic language, there are several expressions that are used for referring to finance lease. Finance lease is sought by the enterprise launcher who needs to be funded to launch or develop an enterprise. Therefore, the enterprise launcher resorts to a company that is specialized in finance lease to conclude a contract with. When the contract with the latter company expires, the enterprise launcher (lessee) shall acquire the ownership of the assets or return them to the lessor.

The meaning of the finance lease under the Latin system is different than the meaning of this term under the AngloSaxon system. Unlike the Latin system, in the Anglo-Saxon system, the lessee may not acquire ownership of the assets when the finance lease contract expires ${ }^{3}$.

Therefore, some scholars define finance lease as: "a funding activity that aims at purchasing specific machines or capital assets to lease them to the lessee in order to be utilized for a long period of time. The finance lease contract can't be cancelled. When this contract expires, the lessee shall become entitled to acquire the ownership of the leased assets". Other scholars define the finance lease contract as "a contract that aims at leasing capital assets to a lessee under a contractual relationship that is concluded between the lessor and the lessee for a specific duration. Under this contract, the lessee shall pay rental"4.

In the Islamic Jurisprudence, finance lease contract is defined as "a binding contract that obliges the lessor to lease movable assets, resources, real estates, or facilities for a specific duration. That applies provided that the lessee pays a specific rental. The lessee shall be entitled to acquire the ownership of the assets in full or partially through paying the sale price that is specified in the contract. When setting this sale price, the amount of rental that has been paid must be taken into consideration. In case the lessee doesn't want to buy the assets, he may return the assets to the lessor or decide to renew the contract" 5

In the researcher's opinion the finance lease contract may be defined as a contract concluded between lessor and lessee that aim at enabling the lessee to utilize the capital assets that are owned or purchased by the lessor. It applies whether these assets are movable assets or immovable ones (i.e. real estates). But it applies provided that the lessee pays a specific amount of rental to the lessor for a specific period of time. When the contract expires, the lessee may havethe right of obtaining the ownership of these capital assets). Western jurists define finance lease contract as (a contract concluded between two parties; the lessor and the lessee. Under this contract, the lessee pledges himself to pay several installments respectively to the lessor, provided that the sum of these installments is higher than the original price of the assets) ${ }^{6}$.

According to some jurists, finance lease contract is(a transaction in which three parties are involved in. It combines two contracts jointly; the sale contract and the lease contract. Under such a sale contract, the financial company (the lessor) shall purchase specific assets. Under such a lease contract, the latter company shall lease those assets to the enterprise launcher (i.e. the lessee), provided that a specific amount of rental shall be paid by the lessee) ${ }^{7}$.

Based on the aforementioned definitions, it can be noticed that there is a difference between the finance lease contract and the lease contract. Both of these contracts share similarities with each other. For instance, they consist

\footnotetext{
${ }^{2}$ AL-SHAFE'Y, MOHAMMAD. Essential Concepts Related to Finance Lease. $1^{\text {st }}$ edition. Amman. Amjad Publication and Distribution house, 2015, p.5-8.

${ }^{3}$ ABDULLAH, MUSTAFA. Finance Lease Contract. MA thesis. Cairo University, 2012, P.18.

${ }^{4}$ AL-SHAWABKEH, MOHAMMAD. Finance lease Contract: A Comparative Study. $1^{\text {st }}$ edition. Amman. Al-Thaqafah Publication and Distribution house, 2012, p. 90-91.

${ }^{5}$ AL-SAYED, ABED AL-MENEM. International Finance Lease Contract: An Analytical Comparative Study about Private International Law. Alexandria. Al-Feker Al-Jame'y publication and distribution house, 2010, P.25

${ }^{6}$ AL-KHZALEH, A. AL-DWIRY, M. To What Extent Does Financial Leasing Has Impact On The Financial Performance Of Islamic Banks: A Case Study Of Jordan. Academy of Accounting and Financial Studies Journal. 2018, 22(1) . p1-14.

${ }^{7}$ ABDULLAH, MUSTAFA. Finance Lease Contract. MA thesis. Cairo University, 2012, P.14.
} 
from three elements; the lessor, the lessee, and the leased asset. However, they differ from one another. That is because the lessee in the finance lease contract shall be entitled to acquire the ownership of the leased asset or return it to the lessor when the contract expires. When the finance lease contract expires, the lessee may become automatically the owner of the leased asset. However, that must be stated explicitly in the contract ${ }^{8}$.

Royal Jordanian Airlines leased most of its planes from a company (i.e. 22 planes out of 29 ones) through contracts leading to the acquisition of ownership. Such contracts are considered finance lease contracts. In the light of that, the Jordanian legislator found it necessary to enact legislative texts that regulate the finance lease contracts. Thus, he issued a bill for the Jordanian finance lease law of 1997. The latter bill doesn't include any definition for the expression (finance lease). Later one, the Jordanian legislator issued the temporary Jordanian finance lease law No. 16 of $2002^{9}$.

In 1984, Jordan Leasing Company in Jordan leased equipment to several companies. However, it stopped operating later on. It was turned into a bank called Amman Bank. That led to freezing the finance lease services in Jordan till 1998. That is because drafting the latter bill led to the creation of few companies that provide finance lease services. Later on, the temporary Jordanian finance lease law No. 16 of 2002 was enacted. Then, the temporary Jordanian finance lease law No. 48 of 2003 was enacted. After that, the Jordanian finance lease law No. 45 of 2008 was enacted to address the shortcomings that exist in the previous temporal laws ${ }^{10}$.

The Jordanian finance lease law No. 45 of 2008 suggests that the provisions of the Jordanian landlord and tenant law mustn't be enforced on the finance lease contracts. That is stipulated through article 26 of the Jordanian finance lease law. Article 27 of the latter law states that "the legislative texts that are listed in any other law and contradict the present law shall not be applie". The Jordanian finance lease law that permits the enforcement of provisions of the Jordanian civil law- in some cases- to the finance lease contract. That applies to the provisions that are related to (capacity, offer \& acceptance, asset and reasons) that are listed in the Jordanian civil law. It also applies to the provisions that are listed in a special chapter titled "the lease contract" in the Jordanian civil law. That applies in accordance with the legal rule that suggests the following "the specific legislative texts shall narrow down the broader legislative texts".

The finance lease contract has a complex nature due to combining several types of contracts jointly. It is considered complex due to having several parties involved in executing and concluding it. It is considered complex due to having a changing nature throughout time. Therefore, it can't be considered a civil contract nor a commercial contract. Hence, it has a special distinctive nature.

Therefore, the Jordanian civil law doesn't regulate the finance lease contract explicitly. It doesn't include an explicit definition for the finance lease contract. In fact, it only identifies the elements of the finance lease contract. Article 2 of the Jordanian finance lease law suggests that the term (finance lease) refers to (an activity through which the lessor purchases specific leased assets through his existent (or borrowed) money in order to lease the asset to a lessee to be utilized. That occurs, provided that a specific amount of rental shall be paid by the lessee. That occurs in accordance with the provisions regulating the lease contract). Article 2 suggests that the expression (lease contract) in this context refers to (the finance lease contract which is regulated and concluded in accordance with the provisions of this law).

To follow, Article 2 of the Jordanian finance lease law states that the "leased asset" refers to "any movable or immovable asset that can be utilized for several times with keep being existent. It states that the leased asset doesn't refer to cash, nor financial nor commercial notes". Definitions are provided in the Jordanian finance lease law for the following terms: (lessor, lessee, and rentals) ${ }^{11}$. After reviewing these legislative texts, the researchers noticed

\footnotetext{
${ }^{8}$ AL-ATTAR, MOHAMMAD. The Global Journal for Islamic Marketing. 2017, 6(3). P.28.

${ }^{9}$ AL-FATAFTAH, HASAN. Finance Lease in Arab Countries: Experience and Development Requirements. Amman. Al-Sho'leh Research and Consultation House. 2007, P.106.

${ }^{10}$ AL-HASNAWI, SALEM. Finance lease and selected applications. $1^{\text {st }}$ edition. Amman. Al-Manhajeye publication and distribution house. 2016, P.30.

${ }^{11}$ Article 2 of the Jordanian finance lease law defines the lessor as (a moral personality who has been registered in accordance with the applicable legislations. The goals of the lessor are represented in carrying out finance lease activities. That applies with excluding the partnership companies and the limited partnership companies). It also defines the lessee as a (natural or moral personality who shall utilize the leased asset in accordance with the terms of the finance lease contract). Under article 3 of the Jordanian finance lease law, to consider a finance lease contract as being valid, there are 2 conditions that must be met:

1-The lessor must acquire the ownership of the leased asset from the supplier in the aim of leasing it to the lessee. That must occur under a finance lease contract.

2-The lessor must enable the lessee to utilize the leased asset in exchange for a specific amount of rental
} 
the following:

1) The Jordanian legislator didn't state explicitly a definition for the term (finance lease contract). However, he provided a definition for each element of this contract.

2) The Jordanian legislator suggests that the lessor in the finance lease contract must be a moral personality. However, he excluded partnership companies and limited partnership companies. Thus, the Jordanian legislator didn't specify the nature of the personality of the lessee in the finance lease contract. He suggests that such a lessee may be a moral or a natural personality.

3) Based on the aforementioned legislative texts, the leased asset in the finance lease contract may be moveable asset or real estate. Thus, the lessee must be capable to use the leased asset with keeping the asset existent when the contract expires. Therefore, the leased asset in the finance lease contract mustn't be a consumable asset. It mustn't be cash, or financial or commercial notes.

4) The goal sought from purchasing the leased asset by the lessor is represented in allowing the lessor to utilize it during the validity period of the finance lease contract. That shall occur, provided that the lessor will remain the owner of the asset during the validity period of the contract $^{12}$.

5) Finally, the lessee is entitled to benefit from the leased asset, provided that a specific amount of rental shall be paid to the lessor.

6) The Jordanian legislator suggested that there are specific elements that must be existent to consider the finance lease contract valid. For instance, such a transaction must be carried out by a Jordanian company that is registered in the Jordanian Ministry of Industry and Trade. The company must be also having a valid professional license. The capital of the company mustn't be less than 1 million JDs ${ }^{13}$.

\subsubsection{The Merits of the Finance Lease Contract}

The finance lease contract is considered a binding contract for both parties. Through this contract, an exchange shall be made between both parties and several responsibilities shall be assigned to both parties (i.e. the lessor and the lessee). The finance lease contract is valid for a specific period of time. It is a legitimate contract under the law. The Jordanian finance lease lawaims at regulating this kind of contracts. It was enacted due to the increasing spread of this kind of contract ${ }^{14}$. The finance lease contract has many merits which are for the favor of the lessor, the lessee and the national economy. For instance, it enables the lessee to fund his enterprise (100\%) without having to pay the required amount of money in full and in advance. The financial company shall purchase the leased property and receive rental from the lessee. The leased property may be moveable property or a real estate ${ }^{15}$.

The finance lease contract enables the lessee to save time. That is because this contract can be concluded fast. During the validity period of the finance lease contract, the lessee shall be capable to utilize the leased asset without having to purchase $\mathrm{it}^{16}$. Through the finance lease contract, the lessee shall be capable to obtain the machines and devices that have the required technical description. The finance lease contract enables the lessee to replace his machines with new ones that he needs. It enables the lessee to save costs. That is because the lessee will not purchase the leased asset at his own expense ${ }^{17}$.

Under the finance lease contract, the lessor shall remain the owner of the leased asset during the validity period of the contract. The finance lease contract serves as an investment carried out by the lessor. Under this contract, in case the lessor experienced bankruptcy or insolvency, he is entitled to retrieve the leased asset and keep the amount of rental that he received ${ }^{18}$. The lessor (i.e. the finance lease company) serves as broker. That's because the lessor (i.e. the finance lease company) doesn't buy the leased asset, without having a written request made by the lessee. Submitting such a request shall protect the lessor from the business risks associated with the finance lease contract. Concluding this contract provides the lessor with a fixed regular income that enables him to launch enterprises in

\footnotetext{
${ }^{12}$ Al-Tawal, Abeer Al-Safadi (2015). Finance lease: The future of the finance industry. $1^{\text {st }}$ edition. Amman. Al-Manahej publication and distribution house. P.16

${ }^{13}$ Al-Attar, Mohammad (2017), op cit. p.34

${ }^{14}$ Al-Khasawneh, Sakher Ahmad (2005). The finance lease contract: A comparative study about the Jordanian laws with referring to Ahkam in Fiqh. $1^{\text {st }}$ edition. Amman. Wa'el publication and distribution house, p.54

${ }^{15}$ Abu Hasweh, Zeyad (2005). Finance lease contract: A comparative study. Beirut. Al-Rai’ publication and distribution house, p.67

${ }^{16}$ Al-Tawal, Abeer Al-Safadi (2015), op cit. p. 41

${ }^{17}$ Abu Hasweh, Zeyad (2005), op cit. p. 69

${ }^{18}$ Al-Hasnawi, Salem SalalRahi (2016). Op cit. p.47
} 
the future and set plans for them ${ }^{19}$. Concluding a finance lease contract with an enterprise launcher serves as an investment opportunity for investors. That is because making such an investment shall provide investors with fixed tax exemption rates, and investment facilities.

The finance lease contract has many merits related to national economy. For instance, it increases the balance of payments in case the contract is international. It reduces the cost of launching enterprises due to the increasing competition between the funding agencies ${ }^{20}$. It increases the number of job opportunities, and people's income, and improves the living conditions of people. It increases the government's revenues which are generated from taxes and fees. That shall participate in developing the state's national economy ${ }^{21}$.

\subsection{The Thematic Conditions of the Finance Lease Contract}

To consider the finance lease contract valid, there must be several thematic conditions met. Such conditions are related to (consent, asset $\&$ reasons).

\subsubsection{Consent in the Finance Lease Contract}

The finance lease contract is a consensual contract that requires the occurrence of offer and acceptance. Article 90 of the Jordanian civil law suggests that "The contract is considered concluded upon the occurrence of offer and acceptance. That applies with taking into consideration the other requirements set by the law for concluding the contract". When concluding the finance lease contract, the lessor and the lessee must be willing to conclude it. Their will must be free from defects, such as: cheating, coercion, and fraud. In addition, both parties must be enjoying the legal capacity required to conclude the contract ${ }^{22}$. Both parties must be approving all the terms of the contract willingly ${ }^{23}$.Under the Jordanian law, the lessor in the finance lease contract must be a financial company or a bank. Such companies and banks must enjoy the required legal capacity. Such capacity is considered existent upon registering themselves in the agency determined by the law ${ }^{24}$.

The finance lease contract is considered a bilateral contract. That is because there are two parties involved in this contract; the finance lease company and the beneficiary. However, in reality, this contract consists from three parties. The third party is represented in the seller of the concerned leased asset ${ }^{25}$. In order to consider offer and acceptance existent in this contract, there are several stages that must occur. The first stage starts when the lessee starts searching for a financer to fund his enterprise. After choosing the funding institution, the lessee shall submit a request to the funding institution for funding his enterprise. Submitting this request serves as an offer and expression for his willingness to conclude a finance lease contract. Such a request must be drafted by the lessor (i.e. the funder). It must include all the relevant information about the lessee. It must be attached with the relevant documents and papers.

In case the lessee is a moral personality, the entity's contract of creation, statute and record at the commercial register must be provided. In such a case, information about the entity's board of directors, manager, and privileges must be provided. In such a case, information must be provided about the banks that the entity deals with. The lessee must provide information about the nature of the enterprise, budget, the loans that have been obtained and the future plan of the enterprise. Information about the intended enterprise must be submitted. Such information is highly important. That's because such information enables the lessor to identify the financial capability of the lessee and how serious the lessee is when requesting to be funded. At this stage, the lessee must be showing honesty and integrity when delivering information. The lessor (funder) shall visit the one requesting to be funded at the site of the enterprise. He must draft a report about the information that he received. He must make sure that the information that he received is valid and correct. He must make sure that that the one requesting to be funded has met the trust criteria that must be met by his customers. He must ensure that the one requesting to be funded is capable of doing the financial obligations listed in the finance lease contract.

Filing the funding request doesn't mean that this request shall be definitely approved by the lessor. Obtaining such an approval depends on the information and the documents submitted by the lessor. In case the lessor found that there isn't any benefit gained from funding the lessee, he shall reject the funding request. That may occur in case

\footnotetext{
19 Al-Shawabkeh, Mohammad Ayed (2011). Op cit. p.101

${ }^{20}$ Al-Hasnawi, Salem SalalRahi (2016). Op cit. 49

${ }^{21}$ Al-Shawabkeh, Mohammad Ayed (2011). Op cit. p.103

${ }^{22}$ Abu Hasweh, Zeyad (2005), op cit. p.130

${ }^{23}$ Nassif, Elias (2008). The finance lease contract under the comparative law. $1^{\text {st }}$ edition. Al-Halabi Publications in Law. Beirut, Lebanon. P. 154

${ }^{24}$ Al-Shawabkeh, Mohammad Ayed (2011). Op cit., p.113

${ }^{25}$ Al-Qalab, Bassam (2009). Finance lease: A comparative study. $1^{\text {st }}$ edition. Al-Raya Publication and distribution house. Jordan
} 
the amount of the rental is small. It may also occur in case the lessor isn't' sure that the lessee shall do the financial obligations listed in the finance lease contract. It may occur in case the lessor found that the lessee isn't serious in the funding request he filed. In case the lessor found that that there are positive indicators in the funding request of the lessee, the lessor shall accept the request and fund the enterprise ${ }^{26}$.

Some people suggest that the funding request serves as an invitation for holding negotiations rather than an offer. Negotiation refers to the process of exchanging suggestions, letters, reports, technical studies, and legal consultations between the concerned parties. It aims at informing both parties about the best legal measures that can meet their interests. It shall lead to concluding the finance lease contract. Concluding this contract shall grant both parties rights and assign responsibilities to them. In other words, some people suggest that negotiations in this regard aim at drafting the terms of the final version of the finance lease contract. Once the finance lease contract is concluded, the negotiations between both parties shall $\mathrm{end}^{27}$.

From the perspective of the researchers of the presents study, filing the funding request serves as an offer made by the lessee. This request must be attached with all the required documents. It must include detailed information about the enterprise. It must be printed. The form of this request must be drafted by the lessor (i.e. the funder). The researchers of the presents study believe that the finance lease contract mustn't be an adhesion contract (i.e. standard form contract). That's because there isn't any reason that may prevent the lessee from holding negotiations with the lessor about the terms of the finance lease contract.

The lessor must be a moral personality as it is stipulated through the Jordanian laws. Under the Jordanian laws, the existence of the lessor must be legal. It must be meeting the required legal conditions. The lessor must be represented by a legal representative who enjoys the required legal capacity ${ }^{28}$.

The expiry of the finance lease contract may lead to the transition of the ownership of the asset from the lessor to the lessee. In case the lessee wanted to acquire such ownership, the lessee must be enjoying the required legal capacity. Under the Jordanian laws, the moral personality must be registered in accordance with the relevant valid legislations. Under the Jordanian laws, the goals of the moral personality that serve as a lessor must include practicing finance lease activities. However, under the Jordanian laws, the partnership companies and limited partnership companies are excluded and thus, they can't serve as lessors.

As for the lessee, he may be a moral or a natural personality. In case the lessor is a natural personality, he must be having the required legal capacity that is required for taking the required legal measures. In case the lessee is a moral personality, its existence must be consistent with the provisions of the law. In case the lessee is a moral personality, a natural personality must conclude the finance lease contract on the behalf of the moral personality. The representative in such a case must be enjoying the power of concluding the contract on behalf of the moral personality. This power must be granted in accordance with the legislations regulating the actions of the moral personality. The representative must be enjoying the required administrative capacity. Several responsibilities shall be assigned to the moral personality that enjoys financial and administrative independence ${ }^{29}$.

Upon concluding the finance lease contract, there shall be responsibilities assigned to the lessee. Such responsibilities include: paying the rental, receiving the leased asset from the lessor and preserving the leased asset. Upon concluding the finance lease contract, several rights shall be granted to the lessee. Such rights include: the right to acquire the ownership of the asset upon the expiry of the contract. Hence, the lessee must be enjoying the required administrative capacity ${ }^{30}$. In addition, under article 7 of the Jordanian finance lease law, in case the lessee is a foreign person or a moral personality, he must obtain the required official approvals to lease a real estate from the lessor. Such approvals must be obtained in accordance with the applicable legislations.

In this regard, it should be noted that the legislator has enacted legislations regulating the kind of the lessee's personality. It should be noted that the lessee must be capable to utilize the leased assets. That must be ensured in order to protect the lessor's assets from being misused. It must be ensured in order to ensure that the lessee shall be capable to handle his contractual responsibilities which are derived from the finance lease contract.

The lessor is entitled to transfer the ownership of the leased asset to another party. That is stipulated through article $8 / \mathrm{b}$ of the Jordanian finance lease law. When doing that, the rights and the responsibilities of the previous lessor shall be transferred to the new lessor. Such rights and responsibilities are identified through the finance lease

\footnotetext{
${ }^{26}$ Al-Khasawneh, Sakher Ahmad (2005), op cit., p.71-75

${ }^{27}$ Al-Shawabkeh, Mohammad Ayed (2011). Op cit., p.116

${ }^{28}$ Nassif, Elias (2008). op cit., p.228-229

${ }^{29}$ Nassif, Elias (2008). op cit., p229

${ }^{30}$ Al-Shawabkeh, Mohammad Ayed (2011). Op cit. 114
} 
contract. Under article 11/a of the Jordanian finance lease law, the lessee may transfer his rights to a new lessee. However, a written approval must be obtained from the lessor on that. In case that occurred, the new lessee shall be held responsible for paying the rental directly to the lessor. That shall be applicable starting from the date on which the lessee was notified in writing about the lessor's approval on the transition. The new lessee shall be having the same rights and responsibilities of the previous lessee. That shall be applicable, unless the lessor and the lessee agree on new contractual terms.

\subsubsection{The Leased Asset in the Finance Lease Contract}

Article 157 of the Jordanian civil law suggests that there must be an asset in each contract. It suggests that such an asset must be existent. The Jordanian finance lease law No. 45 of 2008 defines the leased asset as "any movable or immovable asset that people can be benefit from through using it several times with keep being existent. That applies with excluding cash and commercial or financial notes". Thus, the leased asset in the finance lease contract may be a movable or an immovable asset. The lessee in this contract must be capable to benefit from the leased asset. The leased asset in this contract must be existent or shall become existent. It must be measureable and exchangeable. The transactions related to the leased asset must be consistent with the laws, public orders and morals ${ }^{31}$. Fortunately, under the Jordanian laws, the leased asset may be a moveable or an immoveable asset (e.g. real estate). However, under the laws of other countries -e.g. the Lebanese finance lease law- the leased asset in the finance lease contract must be a moveable asset (i.e. real estate).

Under the Jordanian laws, it's not necessarily for the leased asset in the finance lease contract to be already possessed by the lessor. However, the leased assets in the finance lease contract mustn't be consumable. In other words, they mustn't be machine and equipment that are used for production. They mustn't be real estates that can be only used for productive purposive, such as: factories, hotels, and hospitals. The Jordanian legislator enacted such rules for enabling the lessor to sell the leased asset in case the lessee failed to do his financial obligations. Through being capable to sell the leased asset, the lessor can retrieve back his funds in case such failure occurred. In other words, in case the leased asset is consumable, the lessor won't be capable to sell it and retrieve back his money ${ }^{32}$. The leased assets are categorized into two types, which are:

1) Moveable asset: Article 58 of the Jordanian civil law defines the moveable asset as "any asset except for real estates". Based on the latter article, the real estate is something fixed in its place and can't be transmitted without changing its nature nor damaging it. Any asset other than that shall be considered as a movable asset. The moveable assets include:

A- Financial movable assets: They refer to the machines that one needs to launch a new enterprise or develop an existent enterprise. Financial movable assets may include the machines used in planes, ships, cars, buses and etc.. They may include: the machines used in factories and computer devices. They may include the machines used in medical labs and the machines used for reaping harvest. ${ }^{33}$

B- Moral movable assets: They refer to trademarks, patent and industrial ownership rights and etc. ${ }^{34}$

2) Real estates: Article 58 of the Jordanian civil law defines real estates as (something fixed in its place and can't be transmitted without changing its nature or damaging it. Any asset other than that shall be considered as a movable asset). When intending to conclude a finance lease contract, the real estate to be leased must be owned by the lessor or constructed by the lessor upon the lessee's request. Under the Jordanian laws, the leased asset in a finance lease contract may be a piece of land. Under such laws, each transaction related to a real estate must be registered at the land registry department. ${ }^{35}$

\subsubsection{Reason of Concluding the Finance Lease Contract}

Article 165 of the Jordanian civil law states that reason in this regard refers to "the main goal sought from concluding the finance lease contract which must be existent, valid, legitimate and consistent with the public order and moral system". In the finance lease contract, the reason is represented in the lessee's desire to purchase the concerned assets to fund a new enterprise or develop it. When concluding the finance lease contract, the Jordanian legislator requires having a reason that is existent, valid, legitimate and consistent with the public order and moral system. In other words, there must be legitimate benefits gained by both parties of the finance lease contract.

\footnotetext{
${ }^{31}$ Abu Hasweh, Zeyad (2005), op cit. p. 146

${ }^{32}$ Al-Shawabkeh, Mohammad Ayed (2011). Op cit. p.132

${ }^{33}$ Al-Khasawneh, Sakher Ahmad (2005) op cit., p. 89-91

${ }^{34}$ Al-Khasawneh, Sakher Ahmad (2005) op cit., p. 94

${ }^{35}$ Al-Khasawneh, Sakher Ahmad (2005) op cit., p, 98
} 
Under Article 166 of the Jordanian civil law a contract "shall be considered invalid in case there aren't legitimate benefits gained by both parties of the contract. The existence of such benefits shall be presumed, unless there is a proof suggesting otherwise". Thus, if there isn't any legitimate reason for concluding the contract, the contract shall not be considered valid. Almost all jurists suggest that if one of the parties has an illegitimate reason for concluding the contract, it wouldn't be enough to consider the contract null. In fact, the other party must be negatively affected by the illegitimate reason. Such legislations were enacted to regulate financial transactions and protect the party who has a good intent and didn't know about the illegitimate reason of the other party at the time of concluding the contract. Under the Jordanian law, a party may claim that the contract is null due to being inconsistent with the public order. In such a case, the court shall issue a judgment indicating that the contract is null ${ }^{36}$.

The reason for concluding the contract is the motive of the party who concluded the contract. It differs from one person to another. As for the reason of complying with the contract's terms, it is represented in the thing that the complying party would like to get as a result of showing such compliance. Such a thing may include: obtaining the price of an item. The reason behind complying with the terms of the finance lease contract by the lessee is represented in utilizing the leased asset during the validity period of the contract, provided that a specific amount of rental shall be paid. It is also represented in acquiring the ownership of the lessee when the finance lease contract expires. As for the reason of complying with the terms of the finance lease contract by the lessor, it is represented in obtaining the amount of rental that is specified through the finance lease contract ${ }^{37}$.

\subsection{The Formal Conditions for Concluding the Finance Lease Contract}

Under the Jordanian laws, there are specific formal conditions that must be met when concluding the finance lease contract. That applies despite the fact that the finance lease contract is a consensual contract that requires from both parties to be willing to conclude it. Such formal conditions include: concluding the contract in writing and registering the contract at the concerned registry department.

\subsubsection{Concluding the Finance Lease Contract in Writing}

The finance lease contract is a consensual contract which requires the presence of offer and acceptance. However, due to the special nature of this contract, this contract must be concluded in writing and in accordance with the laws. That is stipulated through the relevant laws. Concluding such a contract in writing shall enable the contract parties to file a claim related to this contract. It is required because this contract has a complex nature. This contract has a complex nature because it consists from several types of contracts jointly. This condition is required because there are several parties involved in concluding and implementing this contract. It is required because claiming for the rights derived from such a contract mustn't depend on the memories of the parties. Otherwise, such rights can be difficult to prove. Concluding this contract in writing shall enable both parties to protect their rights. That is needed to avoid using the leased asset by the lessee as a security for obtaining debts.

In general, the legislator requires concluding contracts in writing in 2 cases. In the first case, concluding the contract in writing is required to prove the contract. In this case, the contract shall be valid even if it wasn't written. In this case, the contract can be proved through other types of proofs, such as: the oath, testament, acknowledgment and clues. In the second case, concluding the contract in writing is one of the elements of concluding it. In the latter case, refraining from writing the contract shall make the contract null ${ }^{38}$. In this regard, one may ask is writing the finance lease contract something required for proving it? or is it one of the elements of concluding it?

Article 5/a of the Jordanian finance lease law includes the following rule: "The finance lease contract must be concluded in writing". As for article $5 / \mathrm{b}$ of the Jordanian finance lease law, it states the following: "The finance lease contract shall be considered null in case it wasn't concluded in writing". That means that refraining from concluded the finance lease contract in writing shall make it null under the Jordanian laws. The finance lease contract shall be considered null in case it doesn't include any of the data that is identified through article 5/a of the Jordanian finance lease law. Such data include: a description for the leased asset, the name of the supplier, the name of the party who chose the leased asset, and the duration of the contract. They also include: the amount of the rental and the dates on which the rental should be paid on. Based on the aforementioned information, concluding the finance lease contract in writing is considered a condition that must be met for considering the contract valid. Otherwise, the contract shall be considered null.

The researchers analyzed the legislative texts listed in the Jordanian finance lease law. Through conducting this

\footnotetext{
${ }^{36}$ Al-Shawabkeh, Mohammad Ayed (2011). Op cit. 112

${ }^{37}$ Abu Hasweh, Zeyad (2005), op cit. p. 150

${ }^{38}$ Abu Hasweh, Zeyad (2005), op cit. p. 102
} 
analysis, he noticed that other legislators adopted another approach in terms of concluding this contract in writing. For instance, under the Syrian legislative decree No. 88 of 2010, concluding this contract in writing is required to prove it. However, under this decree, refraining from writing this contract shall not make it null. That was decided in order to provide the parties with the freedom to do what they desire ${ }^{39}$. The researchers of this study suggested that the Jordanian legislator didn't something good when considering the unwritten finance lease contract null if it wasn't concluded in writing. He believes so due to the complex nature of this contract and having multiple parties involved. Thus, he also believes that such legislations shall protect the rights of all the parties.

\subsubsection{Registering the Finance Lease Contract at the Concerned Registry Department}

Article 15/a of the Jordanian finance lease law states that "Despite anything listed in any other legislations, the finance lease contract that is related to a private moveable assetor real estate must be registered at the concerned official department. Otherwise, the contract shall be considered null. There isn't any fee nor taxes associated with registering this contract". The latter article confirms that the finance lease contract that is related to a private moveable asset or real estate must be registered at the concerned official department. Article 2 of the Jordanian finance lease law defines the private moveable assets as (moveable assets that must be registered at the concerned official department in pursuant to the applicable legislations. Such assets may include: vehicles, planes, and ships).

Through conducting the analysis of the legislative texts listed in the Jordanian finance lease law, The researchers of this study noticed that article 5 of the latter law suggests that specific data must be included in the finance lease contract. Such data may include a description for the leased asset that must enable one to differentiate between the leased asset and any other asset. Such data must include the name of the party who chose the leased asset. It is important to identify the name of this party in order to hold him accountable in case a serious problem resulted due to the failure of the leased asset in meeting the sought goals. In case such failure occurred, the party who chose the leased asset shall be obliged to pay the costs resulting from the occurrence of such failure. That shall occur in pursuant to article 14/e of the Jordanian finance lease law.

In addition, the name of the supplier must be identified. That is necessary in order to hold the supplier accountable for his poor compliance with the terms of the contract. The amount of the rental and the number of the installment must be also identified through the contract. The date on which each installment shall become due must be identified through the contract. The validity period of the contract must be identified through the contract. The terms and conditions regulating the process of submitting the leased asset by the lessor to the lessee must be identified through the contract.

Article 5 explicitly suggests that refraining from concluding the finance lease contract in writing or refraining from listing any of the identified data shall make the contract null. To be specific, it states that "The finance lease contract shall be considered null in case it wasn't concluded in writing. It shall be also considered null in case it doesn't include any of the data mentioned in this article. In any of those cases, both parties shall be entitled to consider the contract as being null. In such a case, the binding effect of the contract shall not be existent".

Under article (15/a) of the finance lease law, any finance lease contract that is related to a private moveable asset or real estate must be registered at the concerned official departments. Otherwise, such a contract shall be considered null. To be followed, under article 16/a/2, the Ministry of Industry and Trade has a record for the moveable leased asset. Listing data about the leased moveable asset and registering its finance lease contract in this record shall be optional. The presence of this record shall enable officials to identify the transactions related to the moveable asset. That shall participate in protecting all the parties who are involved in the finance lease contract $^{40}$. The date of registering the finance lease contract can be used as a proof when filling a lawsuit against any of the signatories or others. The term (others) in this context refers to (anyone who is not a contract party, such as: the debtors and the inheritors of: the lessee, \&the lessor). In this regard, the researchers believe that it's important to consider the unregistered finance lease contract as null. That is because such registration shall protect the rights of the contract parties and others.

As it is mentioned above, Listing data about the leased moveable asset and registering its finance lease contract in the "leased moveable asset" record at the Ministry of Industry and Trade shall be optional. That's stipulated through article 16/a/1 of the Jordanian finance lease law. The form used for making such registration is standard. This form must be filled with data about supervision, the leased item, the supplier, and the date on which the contract will become effective. It must be also filled with data about the date on which the contract will expire. It must be filled

\footnotetext{
${ }^{39}$ Mahfoud, Ali (2015). The formal requirements of the finance lease contract. Tishreen University Journal for Scientific Studies and Research: The series of legal and economic sciences. 37(5). P.476

${ }^{40}$ Mahfoud, Ali (2015). Op cit. 470
} 
with data about whether the contact includes the purchasing option upon the contract expiry or not ${ }^{41}$. So, there are punishments enforced by the legislator on the ones who submit wrong information in this regard.

Under the Jordanian laws, it is permitted for the lessee to lease the leased asset to any third person in exchange for a specific amount of rental. That applies provided that the lessee obtains a prior written approval from the lessor on doing that. In such a case, the lessee shall become the lessor in the second contract. The third party shall serve as a lessee. The second contract is connected with the first contract. Therefore, all the terms that apply to the first contract shall apply to the second contract. So, if the first contract was considered null, the second contract shall be considered null too. In case the lessee didn't obtain a prior written approval from the lessor on leasing the leased asset, the second contract shall be considered null and unbinding ${ }^{42}$.

\section{The Rights and Obligations of the Parties of the Finance Lease Contract under the Jordanian Laws}

The finance lease contract is binding for both parties (i.e. the lessor and the lessee). There are obligations that must be handled by both parties. In addition, there are rights granted to each party under the finance lease contract. The researchers aimed to identify the rights and obligations of the lessor (first section). He also aimed to identify the rights and obligations of the lessee (second section). He aimed to identify such information in accordance with the provisions of the Jordanian finance lease law No. 45 of 2008.

\subsection{The Rights and Obligations of the Lessor under the Finance Lease Contract}

Under the Jordanian finance lease law, the lessor has rights and obligations under the finance lease contract. These rights and obligations are identified below.

\subsubsection{The Obligations of the Lessor under the Finance Lease Contract}

Article $12 / b$ of the Jordanian finance lease law sheds a light on the obligations of the lessor under the finance lease contract. It includes the following statement:

"The obligations of the lessor include the following: 1- The lessor must enable the lessee to utilize the leased asset in accordance with the terms and clauses of the finance lease contract. 2- The lessor must send a written notification to the supplier when concluding the supply contract. Such notification must suggest that the lessor intends to lease the leased asset to the lessee in accordance with the provisions of the Jordanian finance lease law. Such a notification must include the name of the lessee. 3 - The lessor must send a written notification to the supplier informing him about the name of any other lessee involved."

In the light of that, the lessor in the finance lease contract has many obligations in pursuant to the Jordanian laws. Such obligations include enabling the lessee to utilize the leased asset in accordance with the terms and clauses of the finance lease contract. That is done through submitting the leased asset to the lessee. It's done through providing the lessee with a warranty for fixing hidden defects if present.

Based on the general rules stipulated through the chapter titled (the lease contract) in the Jordanian Civil Law, the lessor must submit the leased asset -along with its accessories- to the lessee. The leased asset must be in a good state that enables the lessee to utilize it in full. That is stipulated through article 677/1 of the Jordanian civil law. The latter article states the following: "The lessor must submit the leased asset -along with its accessories- to the lessee in a state that that enables the lessee to utilize it in full as intended"43. Under article 680 of the Jordanian civil law, the provisions that apply to the submission of a sold asset shall apply to the submission of the asset and its accessories in a finance lease contract. That shall apply unless the parties agree to something else. The lessee in the finance lease contract is the one who chooses the leased asset. Therefore, the legislator permits the lessee to contact the supplier in order to ask him to carry out his obligations which are derived from the finance lease contract. Such obligations include the submission of the leases asset ${ }^{44}$.

The leased asset may be submitted directly by the lessor to the lessee. It may be also submitted indirectly. That occurs when submitting the leased asset by the supplier to the lessee. In such a case, the supplier serves as a representative for the lessor ${ }^{45}$. That shall occur provided that the lessor and the lessee have already agreed on the time, place and method of submission of the leased asset. That applies whether the leased asset is a moveable asset

\footnotetext{
${ }^{41}$ Al-Shafe'y, Mohammad Ahmad (2015). op cit., p. 126-129

${ }^{42}$ Al-Shafe'y, Mohammad Ahmad (2015). op cit., p. 70

${ }^{43}$ Al-Khasawneh, Sakher Ahmad (2005) op cit., p. 165

${ }^{44}$ Abu Hasweh, Zeyad (2005), op cit. p. 158

${ }^{45}$ Al-Khasawneh, Sakher Ahmad (2005) op cit., p. 169
} 
or a real estate.

In addition, the lessee must make a submission acknowledgment after receiving the leased item. Through such an acknowledgment, the lessee shall acknowledge that he has received the leased asset. Through such an acknowledgment, the lessee shall acknowledge that he shall handle the responsibilities resulting from such a submission. Through making such an acknowledgment, the lessee shall acknowledge that the submitted leased asset meets the specified technical description. Therefore, after making such an acknowledgment, the lessee can't claim that the leased asset doesn't meet required technical description. After making such an acknowledgment, the lessee shall become responsible for paying the amount of rental that is specified through the contract ${ }^{46}$.

On the other side, in case the submission is indirect, the role of the finance lease company is represented in funding to provide the lessee with the leased asset that meets the specified technical description. In case something went wrong in the submission process and the lessee signed the acknowledgment, the lessee shall be considered responsible for the occurrence of this error. That is stipulated through article 10 of the Jordanian finance lease contract.

In addition, the lessor is obliged to enable the lessee to enjoy the rights he obtained under the finance lease contract. It should be noted that article 681/1 of the Jordanian Civil Law suggests that the lessor is responsible for providing maintenance services to the leased asset and fixing any fault that may negatively affect the utilization of the asset. However, under article 10/5 of the Jordanian finance lease law, the lessee must provide maintenance services to the leased asset at his own expenses. Such provision must be provided in accordance with the terms of the finance lease contract and any other technical standard.

Finally, in order to enable the lessee to utilize the leased asset and enjoy his rights, the lessor must pledge himself to refrain from committing any harassment against the lessee. To affirm that; the lessor must provide the lessee with a warranty for fixing any hidden defects in the leased asset; if existed. That is stipulated through article 684 of the Jordanian civil law. Under the latter article, it is not permitted for the lessor to commit any harassment against the lessee in a manner that hinders the lessee from utilizing the leased asset during the validity period of the contract. Under the latter article, the lessor is not entitled to make a change to the leased asset in a manner that hinders the lessee from utilizing the leased asset during the validity period of the contract. Under the latter article, the lessor is not entitled to commit an act that hinder the lessee from utilizing the leased asset in the manner stated in the contract. Otherwise, the lessor shall be held liable for such acts of harassment and obliged to provide compensation.

In the light of that, if the finance lease company committed acts that enable the supplier or the seller to commit such harassment against the lessee, the company shall be held liable and obliged to provide compensation. Such acts include: refraining from paying the price of the leased asset to the supplier or the seller. The company shall be held liable and provide a compensation in case it bought assets that do not meet the technical description that was agreed upon through the finance lease contract ${ }^{47}$.

Thus, Article 686 of the Jordanian civil law states that the lessor must provide the lessee with a warranty for the hidden defects in the leased item -if present. That applies provided that such defects must hinder the lessee from utilizing the asset or serve as major shortcoming. Under such article, such a warranty doesn't cover the defects that are accepted under the rules of custom nor the defects that the lessee was aware of at the time of concluding the contract.

However, under article 13 of the Jordanian finance lease law, the finance lease company is exempted from providing a warranty for any defect in the leased asset. That applies unless there is a contract that suggests otherwise or this company is the one that has chosen the supplier. Therefore, the latter article suggests that the finance lease company shall be exempted from providing a compensation for any damage resulting from having a defect in the leased asset. That applies regardless of the type of the defect and the time passed before it appeared. However, the lessee is entitled to file a lawsuit against the supplier and demand the supplier to provide a warranty. That is stipulated through article $13 / 2$ of the Jordanian finance lease law $^{48}$.

Article 14/a of the Jordanian finance law suggests that the lessee is the one responsible for the preservation of the leased asset and shall be held liable in case the leased asset got destroyed or damaged starting from the date of the actual submission. It also suggests that the lessee shall be held responsible for the misuse of the leased asset and any other risk starting from the date of the actual submission. That shall apply unless the parties agree to something

\footnotetext{
${ }^{46}$ Al-Khasawneh, Sakher Ahmad (2005) op cit., p. 169

${ }^{47}$ Al-Badali, Al-Sa'eer (2005). The finance lease contract. Al-Jame'a Al-Jadeeda publication and distribution house. Alexandria, p.318

${ }^{48}$ Al-Sa'eer, Hussam (1994). Finance lease. Al-Nahda Al-Arabeye publication and distribution house. Beirut, p.24
} 
else. Under article 14/b of the Jordanian finance law, if the leased asset got destroyed due to force majeure or any reason that is beyond the lessee's control, the lessee shall remain responsible for carrying out his contractual obligations which are listed in the finance lease contract even.

Under Jurisprudence and the Jordanian Civil Law, the lessor is responsible for the repair of the leased asset in case it got destructed or damaged. Thus, under Jurisprudence and the Jordanian Civil Law means, the lessee shall be entitled to terminate the contract and shall be exempted from doing his contractual obligations in case the leased asset got destructed or damaged ${ }^{49}$.However, to avoid having a contradiction between the Jordanian civil law and the Jordanian finance law, the legislator oblige people to enforce articles 26 and 27 of the Jordanian finance law on finance lease contract.

Thus, under article 12 of the Jordanian finance law, the lessor's obligations include: funding the lessee. To be specific, the lessor is responsible for purchasing the leased asset in order for the lessee to utilize it. That applies in case the lessor doesn't own the leased asset. In such a case, the lessor must purchase the asset that meet the technical description that is provided by the lessee. However, the lessor is entitled to approve or reject the offer made by the lessee before concluding the contract. In case the lessor reject the offer, the lessor shall not have any obligation to do for the favor of the lessee or the supplier ${ }^{50}$. However, some jurists suggest that the lessor should be held liable sometimes for his rejection. That applies in case the lessor rejected the offer without providing any logical or legal reason or justification ${ }^{51}$. In case the lessor refused to fund the lessee after concluding the finance lease contract, the lessor shall be held liable ${ }^{52}$.

With regards to the Jordanian finance lease contract, there are several obligations that must be performed by the lessor. For instance, the lessor must transfer the ownership of the leased asset to the lessee upon the expiry of the contract in case that's stipulated through the contract ${ }^{53}$. That's because the leased asset serves as a security during the validity period of the contract from the perspective of the lessor. Thus, if the finance lease contract expires and the lessee has fulfilled all his contractual obligations, the lessor shall become obliged to transfer the ownership of the leased asset to the lessee in case the contract requires so. The lessor must notify the supplier in writing about his intention to lease the leased asset to a lessee. In such a notification, the lessor must identify the name of the lessee and the name of any other lessee in pursuant to article 12/b/2 of the Jordanian finance law. For instance, in case the leased asset was leased to another lessee, the lessor must notify the supplier in writing about that within 30 days starting from the date on which the lessor acknowledged that.

\subsubsection{The Rights of the Lessor under the Finance Lease Contract}

Under the Jordanian finance lease law, there are several rights granted to the lessor in the finance lease contract. Such rights are mentioned through article 12/a of the Jordanian finance law. Under the latter article, the lessor is entitled to request the lessee to provide any financial data or documents that are related to the finance lease contract. $\mathrm{He}$ is entitled to request that during the validity period of the finance lease contract. The lessor and his representative are entitled to check the leased asset to make sure that it is still in a good state and under the custody of the lessee. That applies, provided that such checks shall not cause any damage to the lessee.

In addition, if the lessee doesn't want to purchase to purchase the leased asset, the lessor shall be entitled to retrieve back the leased asset from the lessee upon the expiry of the finance lease. The lessor is entitled to transfer his rights to another person, provided that the finance lease contract allows that. The binding impact of such a transfer on the lessee shall be considered existent starting from the date on which the lessee was notified in writing. Making such a transfer shall not deprive the lessee from any of his rights nor add additional obligations to his existent obligations.

\subsection{The Obligations and the Rights of the Lessee under the Finance Lease Contract}

Under the Jordanian laws, there isn't any obligation that must be fulfilled by the lessee to the supplier. Under such law, there are obligations that must be fulfilled by the lessee to the lessor. Through the first sub-section, the researchers shed a light on the obligations that must be fulfilled by the lessee. Through the second sub-section, the researchers shed a light on the rights granted to the lessee.

\footnotetext{
49 Al-Qdah, Adam and Al-Qudah, Mousa (2016). The obligations and rights of the lessor and the lessee under the finance lease contract: A comparative study between Fiqh and the Jordanian law. Dirasat Journal: Shariah and Legal Sciences, 43(1),p.248

${ }^{50}$ Al-Khasawneh, Sakher Ahmad (2005) op cit., p. 164

${ }^{51}$ Nassif, Elias (2008) op cit., p. 301

${ }^{52}$ Al-Khasawneh, Sakher Ahmad (2005) op cit., p. 164

${ }_{53}$ Abu Hasweh, Zeyad (2005), op cit. p. 167
} 


\subsubsection{The Obligations of the Lessee under the Finance Lease Contract}

Under article 11/1 of the Jordanian finance lease law, there are several obligations that must be fulfilled by the lessee under the finance lease contract. Such obligations include: paying the amount of rental on the due dates without showing any delay. This obligation is considered the most important obligation among the lessee's obligations. To be specific, the lessee must pay the amount of rental as it is specified in the contract in terms of: due date, place, and method of payment. That shall apply regardless of what is stated in any other law. In case the parties didn't reach an agreement on the due date, place, and method of payment, the general rules shall be considered applicable.

The amount of rental is determined based on the financial value of the leased asset. It is also determined based on the costs incurred by the lessor in order to execute the contract. However, when determining the amount of the rental, the lessor and the lessee must agree on the method of payment. To illustrate more, the rental may be paid in a monthly, annual or seasonal manner. For instance, if the leased asset is an agricultural land, the rental is usually paid in a seasonal manner. One may ask: (In case the finance leas contract got terminated, what is the measure taken on the amount of rental that has been already paid?).

Under article 20/a/2 of the Jordanian finance lease law, it is permitted for the lessor to terminate the contract through a court judgment or through sending a notification. That applies provided that the contract permits doing that. It also applies in case the lessee failed to pay the agreed upon rental. In such a case, the lessor is entitled to keep the amount of rental that he has received from the lessee. That shall apply with taking into consideration: the financial value of the leased asset, the validity period of the contract, the extent of consuming the leased asset and the financial capability of the lessee to pay the rental. In this regard, it should be noted that some finance lease companies oblige the lessee to provide guarantees to ensure that he shall pay the rental ${ }^{54}$.

The lessee must receive the leased asset from the lessor in the state that has been agreed upon in the contract. If the lessee refused to receive the leased asset without providing a justification, the lessee shall be held liable. In such a case, the lessee shall be obliged to fulfill his contractual financial obligations. It should be noted that the lessee is entitled to reject receiving the leased asset in case it doesn't meet the agreed upon description. The lessee is entitled to reject receiving the leased asset in case there is a defect that hinders the lessee from utilizing the leased asset.

The lessee must utilize the leased asset in the manner that has been agreed upon and the goal it was created for. That is stipulated through article $10 / \mathrm{b} / 3$ of the Jordanian finance lease law. In case that didn't occur, the lessor is entitled to terminate the contract. If the contract doesn't illustrate the manner of utilizing the leased asset, the leased asset must be utilized in a manner that fits with its nature and the circumstances. The lessee must seek preserving the leased asset while using it. Therefore, the leased asset must be used by the ones who have adequate expertise.

Under article 12/a/2, the lessee must properly utilize the leased asset with keeping it in a good state. The lessor is entitled to make sure that the leased asset is properly utilized through making field visits. Through making such visits, the lessor can check that the leased asset is still under the custody of the lessee. Through making such visits, the lessor can check that the state of the leased asset in accordance with the rules of custom. It should be noted that the contract must suggest that the leased asset must be used in accordance with the goals that it was created for. The contract may include so, whether the leased asset is a real asset or a moveable asset $t^{55}$.

In short, the lessee must provide maintenance services to the leased asset and seek preserving it. Under article $10 / b / 5$ of the Jordanian finance lease law, the lessee must provide maintenance services to the leased asset and seek preserving it at his own expense. Under the later article, the lessee must pay -at this own expense- the taxes, expenses, and fees that are associated with the leased asset. The lessee is entitled to make additions and improvements to the leased asset. That shall apply unless there is an agreement that states otherwise. For instance, the lessee may find it necessary to make additions to the leased asset to keep being capable of utilizing it. Such additions shall become part of the leased asset. They shall enable the lessee to raise his performance level and develop his works ${ }^{56}$.

Under Jurisprudence, the lessee is obliged to pay -at his own expense-the operational maintenance costs of the leased asset. Such costs are often incurred due to the utilization of the leased asset by the lessee. Under Jurisprudence, the lessor must pay the primary costs. That is because the lessor is responsible for ensuring the survival of the leased asset. Under the Jordanian finance lease law, the lessee is obliged to pay - at his own expense

\footnotetext{
${ }^{54}$ Al-Shawabkeh, Mohammad Ayed (2011). Op cit. 168-173

55 Al-Khasawneh, Sakher Ahmad (2005) op cit., p. 197-198

${ }^{56}$ Al-Khasawneh, Sakher Ahmad (2005) op cit., p. 176
} 
- the operational maintenance and the primary $\operatorname{costs}^{57}$.

The lessee must keep the leased asset in the same state he has received. That applies with excluding the changes that may occur to the leased asset due to using it. It applies with excluding the changes that are stated in the contract. The lessee mustn't make changes to the leased asset in a manner that dramatically alters its structure. That shall apply, unless there is a need for making such changes in order to keep being capable to utilize the leased asset. That shall exempt the lessor from paying any cost that the lessee needs.

Thus, the lessee is obliged to pay the expenses needed for making the changes needed to keep being capable to utilize the leased asset. As for the Jordanian civil law, it adopts a different approach in this regard. Under article 682 of the Jordanian civil law, if the lessee repaired things in the leased asset for the benefit of the lessor and with getting the lessor's approval, the lessee can demand the lessor to pay off the costs that has been incurred. Under the latter article, if the lessee made repairs for his own benefit, the lessee shall not be entitled to demand the lessor to pay off the costs he has incurred. That shall apply unless both parties have agreed to something else. Under the Jordanian finance lease law, the lessee is obliged to pay - at his own expense - the operational maintenance costs and the primary costs. That was decided due to the special nature of the finance lease contract. For instance, when the finance lease contract expires, the lessor shall probably obtain the ownership of the asset. Therefore, he should pay such costs at his own expense.

Both parties may agree on returning the leased asset to the lessor upon the expiry of the contract or on inactivating the purchasing clause in the contract. The finance lease contract may be terminated due to refraining from paying the agreed upon rental. In any of those cases, the leased asset must be returned to the lessor on the agreed upon time and in accordance with the terms of the finance lease contract. However, the lessor must return the leased asset in the state he has received $\mathrm{it}^{58}$. Contrary to the general rules, if the contract expires and the lessee must return the leased asset to the lessor, the lessee must return the asset in the agreed upon state, rather than in the state he has received it. That is attributed to the special nature of the finance lease contract. To illustrate more, the validity periods of the finance lease contracts are usually long. Due to such a long period of utilization, the leased asset shall become in a different state ${ }^{59}$.

\subsubsection{The Rights of the Lessee under the Finance Lease Contract}

Under article 11/a of the Jordanian finance law, there are several rights granted to the lessee. For instance, the lessee is entitled to transfer his rights to another lessee. That applies provided that the lessor's approval is obtained. In such a case, the new lessee must pay the rental to the lessor, starting from the date on which the lessee was notified in writing about the lessor's approval. Such a notification must be sent by the lessor. The new lessee shall have the same rights and obligations that the previous lessee used to have. That shall apply unless the lessor and the new lessee agree to something else. However, contrary to the general rules, under the Jordanian laws, the lessor must approve the transfer of the rights and obligations of the previous lessee to the new lessee. Thus, the lessee isn't entitled to surprise the lessor with making such a transition. That's because the lessor must check the financial capability of the new lessee.

The lessee is entitled to file a lawsuit against the supplier directly in order to demand him to fulfill his contractual obligations in accordance with the terms of the supply contract. In such a case, the lessor must supply the lessee with all the necessary information and documents. In such a case, the lessor must take the measures that shall enable the lessee to file such a lawsuit. The lessor must do that in pursuant to article 13/b of the Jordanian finance law.

Article 13/b of the Jordanian finance law, refraining from doing that shall make the lessor responsible for doing the supplier's responsibilities. The lessee is entitled to file a lawsuit against the supplier directly in order to demand him to fulfill his contractual obligations in accordance with the terms of the supply contract. That is because such non - fulfillment shall hinder the lessee from obtaining his rights which are listed in the finance lease contract. In case the lessee received the leased asset directly from the supplier, the lessee shall be entitled to file a lawsuit against the supplier to demand him to reduce the price due to hidden defects or not meeting the agreed upon specifications. In case the lessee received the leased asset directly from the supplier, the lessee shall be entitled to file a lawsuit against the supplier to demand him to pay a compensation due to a delay in the fulfillment of obligations $^{60}$

\footnotetext{
${ }^{57}$ Al-Qdah, Adam and Al-Qudah, Mousa (2016). op cit., p. 248

${ }^{58}$ Nassif, Elias (2008) op cit., p. 326

${ }^{59}$ Abu Hasweh, Zeyad (2005), op cit. p. 189

${ }^{60}$ Al-Khasawneh, Sakher Ahmad (2005) op cit., p. 224
} 


\section{Conclusion}

Through this study, the researchers identified the meaning of finance lease. Through the finance lease contract, the funder (i.e. the lessor) shall fund the enterprise launcher (i.e. the lessee) in order to purchase a specific leased asset to be utilized. Such a contract shall enable the lessee to have access to the required machines without having to pay the price of the machines in full and in advance.

Through this study, the researchers identified the significance of finance lease contract. For instance, this contract shall enable the enterprise launchers to fund their enterprises. That is needed in developing countries. Thus, such a contract shall enable developing countries to develop their economy. That shall enable developing countries to keep up with the latest developments in the fields of technology and industry.

Through this study, the researchers identified the thematic and formal conditions of concluding such a contract. Through this study, the researchers identified the rights and obligations of the lessor and the lessee under the finance lease contract. The researchers concluded the following results:

1) Jordanian legislator didn't provide a definition for the finance lease contract. That occurred though this contract is very important. For instance, it plays a significant role in achieving economic development and meeting the requirements of launching big enterprises in terms of funding. It can meet such requirements in a quick and flexible manner.

2) Through the Jordanian civil law, the Jordanian legislator identified several thematic and formal requirements for considering contracts as valid.

3) Since the third millennium, the Jordanian legislator becomes aware of the significance of the finance lease contracts in Jordan. Therefore, he issued the temporary Jordanian finance lease law No. 16 of 2002. Later on, he issued the Jordanian finance lease law No. 45 of 2008.

In the light of the aforementioned information, the researchers recommend to:

1) Adding explicitly a definition for the expression (finance lease contract) in the Jordanian laws. Such a definition must identify the elements and parties of this contract.

2) Making the registration of the finance lease contracts that concern the moveable assets obligatory in the moveable leased asset record at the Ministry of Industry and Trade. Under the Jordanian laws, the one who submit wrong data to the registry department about the asset shall be punished for a period that is not less than 3 months, or obliged to pay a fine that is not less than $1000 \mathrm{JDs}$ and doesn't exceed $5000 \mathrm{JDs}$, or both penalties may be enforced on him. The same shall apply to the one who changes any of the data listed on the statement placed on the moveable asset. That is stipulated through article 16/g of the Jordanian finance lease law.

\section{References}

Abu Hasweh, Z. (2005). Finance lease contract: A comparative study. Beirut. Al-Rai' publication and distribution house.

Al-Fataftah, H. M. (2007). Finance lease in Arab countries: Experience and development requirements. Amman. Al-Sho'leh Research and Consultation House.

Al-Hasnawi, S. S. (2016). Finance lease and selected applications (1st ed.). Amman. Al-Manhajeye publication and distribution house.

Al-Khasawneh, S. A. (2005). The finance lease contract: A comparative study about the Jordanian laws with referring to Ahkam in Fiqh (1st ed.). Amman. Wa'el publication and distribution house

Al-Sayed, A. A.-M. H. (2010). International finance lease contract: An analytical comparative study about private international law. Alexandria. Al-Feker Al-Jame'y publication and distribution house.

Al-Shafe'y, M. A. (2015). Essential concepts related to finance lease (1st ed.). Amman. Amjad Publication and Distribution house.

Al-Shawabkeh, M. A. (2011). Finance lease contract: A comparative study (1st ed.). Amman. Al-Thaqafah Publication and Distribution house.

Al-Tawal, A. A.-S. (2015). Finance lease: The future of the finance industry (1st ed.). Amman. Al-Manahej publication and distribution house.

Nassif, E. (2008). The finance lease contract under the comparative law (1st ed.). Al-Halabi Publications in Law. Beirut, Lebanon.

The Jordanian Civil Law No. 43 of 1976. 
The Jordanian finance lease law No. 45 of 2008.

\section{Copyrights}

Copyright for this article is retained by the author(s), with first publication rights granted to the journal.

This is an open-access article distributed under the terms and conditions of the Creative Commons Attribution license (http://creativecommons.org/licenses/by/4.0/). 